\title{
What a difference a decade makes: Jessie and Mina, the two wives of Queensland Premier Sir Robert Philp (1851-1922)
}

\author{
LYNDON MEGARRITY AND LYNE MEGARRITY
}

\begin{abstract}
My Dear Dorothy, - In spite of the fact that we are well into the middle of April, that we are having cooler weather, and that many of our absentees are returning, Townsville continues as dull as ever; there is not a ball nor private dance even in participation, and the only dinners given lately have been strictly masculine ones, at which we have not been able to have a peep. They have been given for the special purpose of entertaining ... Robert Philp, and other celebrities who have been for a few days in town. ${ }^{1}$
\end{abstract}

As the above quote from an 1889 edition of the Queensland Figaro and Punch implies, Queensland public life in the late nineteenth century often excluded women. Aside from reporting attendance at balls, participation in concerts and the unlucky ones caught in law disputes, the lives of women were not a major theme of the print media of the age. However, as the population grew, and Queensland developed more educational and cultural institutions, a small but increasing group of elite British-Australian women developed a respected place in public life, especially in relation to charitable work. Arguably, this outcome reflected the subtle influence of female suffrage, which encouraged a greater role for women outside the home.

The lives of Jessie and Mina, the first and second wives of Robert Philp, mirrored the transition of elite women from being mostly confined to the domestic world to having a more influential place in Queensland society in the early twentieth century. The first Mrs Robert Philp, Jessie, lived entirely in the mid to late Victorian era, and did not enjoy the same freedoms and increased expectations of the second Mrs Robert Philp, Mina, born just over a decade after Jessie in 1867. As this article will show, that decade made all the difference to their quality of life and the values and assumptions that they developed as the wives of Robert Philp, a merchant who later became premier of Queensland (1899-1903, 1907-08). ${ }^{2}$

\footnotetext{
1 'The Lady in Townsville', Queensland Figaro and Punch, 27 April 1889, 12.

2 General biographical details for Sir Robert Philp in this article are found in Lyndon Megarrity, 'The Life and Times of Sir Robert Philp', Queensland History Journal 23, no. 5 (May 2017): 328-43.
} 
In order to tell the life story of Jessie, this article has drawn heavily on the Philp Family Collection at the Fryer Library (University of Queensland). This archival source contains the only known selection of letters by Jessie Philp, written between 1874 and $1890 .^{3}$ Although there are many gaps in her correspondence, enough material survives to provide historians with some understanding of her personality, attitudes and relationships. Published in 1990, a history of the Campbell family compiled by descendants also provides useful biographical details about Jessie and her extended family. ${ }^{4}$

While some contemporary newspaper articles mention Jessie, it is mostly in passing. Mina, by contrast, enjoyed a much higher profile as the wife of a major Queensland politician, and it is possible to trace her activities and interests through the Brisbane press. Unfortunately, unlike Jessie, it is impossible to know much about Mina's inner world, because no known collection of her letters has survived. Despite these limitations, sufficient primary source material on both Jessie and Mina exists to enable historians to compare and contrast what is known of their life experiences and set them within their historical context.

This article aims to assist with the current historiographical emphasis on ensuring that the lives of women in the colonial and early Federation era are better understood. ${ }^{5}$ While there are now many biographical portraits of pioneering women in the professions such as teaching and nursing, and the diaries and memoirs of rural women have given insights into the isolation and challenges of bush life, numerous female stories remain hidden from view. ${ }^{6}$ This is largely because during the nineteenth and early twentieth centuries, the cultural model of the male breadwinner and the female domestic caregiver privileged men as public figures. ${ }^{7}$ Nevertheless, private correspondence, newspaper reports and other sources can help historians create biographical narratives that highlight the agency of women and girls, and the limits of that agency, in a very masculinist cultural environment.

\footnotetext{
3 Philp Family Collection, UQFL28, Fryer Library, University of Queensland (hereafter 'PFC').

Allison Campbell and Morag B. Campbell, The James Campbell Story (Brisbane: Watson, Ferguson \& Co., 1990).

See Malcolm Allbrook and Melanie Nolan, 'Australian Historians and Biography', Australian Journal of Biography and History, no. 1 (2018): 12-13.

6 For Queensland examples of women's biography, see Heather Grant, Great Queensland Women (Brisbane: State of Queensland, 2005); Helen Gregory, “"The Hearts That Made the Nation”: Fleshing Out the Stereotype', Journal of the Royal Historical Society of Queensland 20, no. 5 (February 2008): 159-68; Trisha Fielding, Neither Mischievous Nor Meddlesome: The Remarkable Lives of North Queensland's Independent Midwives 1890-1940 (Townsville: North Queensland History Press, 2019).

7 See Penny Russell, 'Gender and Colonial Society', in The Cambridge History of Australia, vol. 1, Indigenous and Colonial Australia, ed. Alison Bashford and Stuart Macintyre (Port Melbourne: Cambridge University Press, 2013), 462-86; Glenda Strachan, 'Women, Work and the Role of the Male Breadwinner Concept', Queensland Journal of Labour History, no. 28 (Autumn 2019): 45-57.
} 


\section{'Much beloved' by her 'multitude of friends': Jessie's story}

Jessie Bannister Campbell was born on 1 March 1856 in Mary Street, North Brisbane. She was the eldest daughter of prominent Brisbane plasterer and lime cement merchant James Campbell and his wife Isabella (née Mitchell). ${ }^{8}$ Of Scottish origin, the Campbell family arrived in Queensland in 1853 and prospered in the colony due to the success of patriarch James's business interests, which later included milling timber and branching out into shipping. They were later joined by many of James's relatives from the home country. The Campbells were at the centre of a network of Scottish families who settled in Brisbane and attended the Creek Street Presbyterian Church. Jessie's father was prominent in the local community as a spokesman for Scottish migrants. ${ }^{9}$

An early photograph of Jessie was taken circa 1866, posing with her younger sisters Helen ('Nell', b. 1858) and Isabella ('Bella', b. 1862). We see a quietly confident girl who is protective of her sisters (Figure 1). She happily holds Bella's hand and gazes proudly at the camera lens. Jessie knows she is dressed well; her hair is carefully styled, and her boots and spats are clean and little worn. Perhaps this photograph was taken to send to her Scottish relations_-perhaps it rested on the piano at home, on view for family visitors. The photo of the 3 sisters mirrors the growing social and economic status of their father, described around this period by their Aunt Jessie:

Well to begin with James. He has got another son since I wrote last, so that is seven of his family he has got. He carries on his trade and is employing a great many here sometimes 40 or 50 at a time. He also keeps a Lime and Cement store. He would do exceedingly well only for the heavy losses he meets with. It is hard to be in business. James is very steady and pushing ... ${ }^{10}$

Jessie Bannister Campbell, Queensland Birth Certificate, 1856/B/20.

For the life of James Campbell, see A. L. Lougheed, 'Campbell, James (1830-1904)', Australian Dictionary of Biography, National Centre of Biography, The Australian National University, adb.anu.edu.au/biography/campbelljames-5490/text9337, originally published 1979, accessed online 19 January 2020.

10 Letter from Jessie Campbell (sister of James) to her uncle and cousin, undated circa 1860s, Campbell Family Papers, OM 90-41, John Oxley Library. 


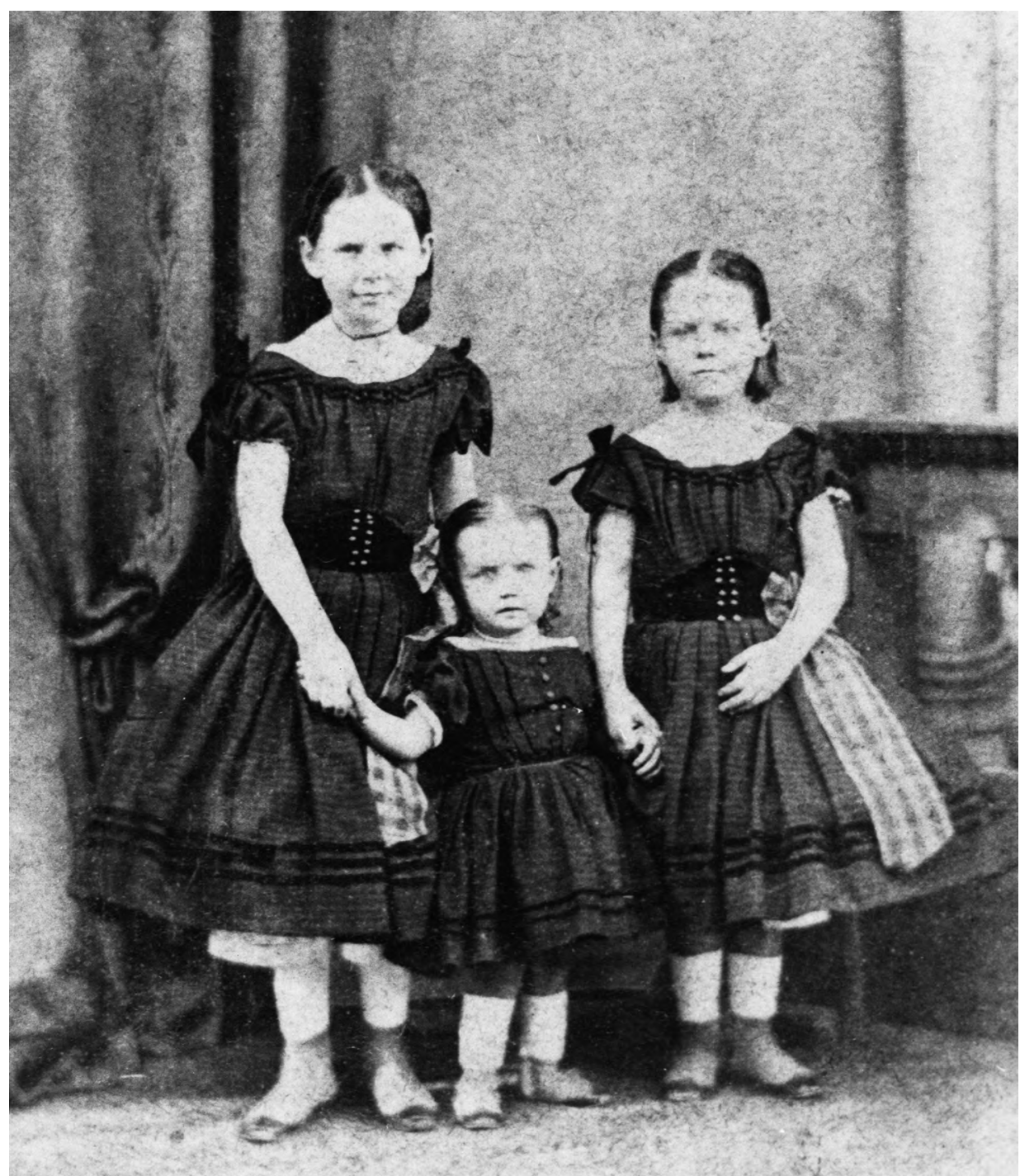

Figure 1: The Campbell sisters circa 1866. L to R: Jessie, Isabella (Bella) and Helen (Nell).

Source: State Library of Queensland.

It is not known where Jessie received her education, but it is likely that she attended the Brisbane Central Girls School, not far from the Normal School attended by her older brother John Dunmore Campbell. ${ }^{11}$ The extent of her formal education remains a mystery, but it is more than likely that she also learned to play a musical

11 'Death of Mr. J.D. Campbell', Brisbane Courier (hereafter BC), 21 June 1909, 5. For Brisbane Central State Girls School, see Queensland State Archives, 'Brisbane Central State Girls School', www.archivessearch.qld.gov.au/ Search/AgencyDetails.aspx?AgencyId=10552\#bookmarkDescription. 
instrument: the Campbells enjoyed regular concerts in the family home. ${ }^{12}$ It was as a schoolgirl that she met Robert ('Bob') Philp, who arrived in Brisbane with his Scottish family in 1862 aged 10 and briefly attended the Normal School, earning the nickname 'Scotchie'..$^{13}$ 'Dear Jessie,' Philp later wrote, 'think of me as the Boy who loved you but a very short time after we met when you were going to School \& who has never ceased to love you. ${ }^{14}$

Indeed, most of the information that exists concerning Jessie's experiences as a young woman is found within her letters to 'Bob' Philp, the young businessman who ultimately co-founded the shipping and trading company Burns, Philp \& Co. For the most part, Jessie's correspondence reveals the values and expectations of women in late nineteenth-century colonial Australia. Girlhood was mainly viewed as training for the day when a woman would marry, look after the household and raise a family. A strong influence on Jessie's attitudes was the example of her mother, Isabella, who raised 5 sons and 3 daughters between the 1850s and the 1880s; she would later provide advice and assistance to her eldest daughter when she herself became a mother. ${ }^{15}$ It is likely that Jessie's outlook was also coloured by the romantic fiction of her era. As historian Alan Atkinson reflected:

Worldwide [from the 1840s onwards], there was now a flood of cheap works of fiction, whose authors asked no more of their readers [than] an interest in courtship, marriage, and womanly sacrifice ... in such ways women learned new things about womanhood. Reading novels was done silently and alone, but in imagination it drew women together. ${ }^{16}$

The earliest surviving letter from Jessie to Robert is dated 17 February 1874, when Jessie was visiting her relatives in Maryborough. ${ }^{17}$ The letter depicts a young 17 -yearold girl, fully involved in an elite community of mostly young colonists of Scottish heritage, many of whom were linked by family and business ties. As she gently teases her male correspondent, there is a strong sense of Jessie testing the boundaries of the submissive, genteel behaviour expected of a young, marriageable, church-going woman in the 1870s while still remaining defined by them:

12 Jacqueline Whiteley, 'Two Families of Early Brisbane: A Study of the Families of Andrew Petrie and James Campbell Through Three Generations, 1830-1910' (BA (Hons) thesis, University of Queensland, 1963), 90. In her correspondence, Jessie encouraged Robert Philp to get involved in the Townsville musical scene, insisting that 'you could sing if you would cultivate your voice a little'. Jessie Campbell to Bob Philp, 25 May 1877, PFC.

13 W. Street, 'Normal School: Recollections of Days in 1863', BC, 3 June 1922, 17.

14 Bob Philp to Jessie Campbell, 13 May 1877, PFC.

15 'Mrs James Campbell', Week (Brisbane) (hereafter Week), 1 March 1918, 25. 'I had serious thought of packing up \& leaving today for Townsville but Mother would not hear of it \& says I not to mention it again till Baby [Isabella Mary Philp] is alright.' Jessie to Robert Philp, 4 July 1879, PFC. See also Allison Campbell and Morag B. Campbell, The James Campbell Story (Brisbane: Watson, Ferguson \& Co., 1990), 2-10.

16 Alan Atkinson, The Europeans in Australia: A History, vol. 2, Democracy (South Melbourne: Oxford University Press, 2004), 149.

17 This is likely to have been her Aunt Jessie, who married George Stupart of Maryborough in 1869. See Campbell and Campbell, The James Campbell Story, 10. 
Dear Robert, I received your letter yesterday \& was rather surprised I must own at seeing it. I do not know what to say to you about it, but I suppose I must not scold, as it would be more than 'human nature' can bear, to be kept so long without a letter from me ... I gave [Philp's brother John] a good scolding for talking in church, but I am afraid it did not do him much good ... I met Gavin ... at a party last week, I refused to be introduced to him, and I never let on I saw him; he told Miss Marshall that he was ashamed to look me in the face $\&$ it would give a lesson in future not to be so foolish ... I have had plenty of riding both here $\&$ at the Bay and also plenty of flirting/rather too much, for it was getting serious but that is over now ... Mother wants me home again ... The [Maryborough] people would like to keep me longer, but when I take it in my head to go they can't stop me, I am so fond of my own way you know ... I am not going to answer any serious questions yet. ${ }^{18}$

In January 1875, Robert Philp moved to Townsville as local manager of James Burns' general store. By 1876, Burns decided to leave the north and installed Philp as his partner in what was to become the mercantile and shipping firm Burns, Philp \& Co. (established 1883). Meanwhile, Philp remained in touch with Jessie. Mary K. Brice, Jessie's granddaughter, relates the family story that when Jessie and her mother began their trip to Scotland in February 1876, 'Philp ... was on the wharf to see her [Jessie] off ... another admirer of Jessie's was actually on the ship, travelling to Scotland too'. Robert was consequently afraid that Jessie 'may be lost to him!'19

There are two potential candidates who may have hoped for a shipboard romance with young Jessie. The first was a young businessman associated with Burns and Philp, Adam Forsyth, who, along with 'Mrs and Miss Campbell', is listed in the newspapers as travelling on the same steamship journey to England. ${ }^{20}$ Some time after her return from Scotland, Jessie wrote to Philp about a tense encounter with the Forsyth brothers back in Brisbane. James Forsyth accused Jessie of having spread rumours about his brother Adam, the nature of which decorum appears to have dictated that she not reveal:

I was indignant of course, but ... Mother gave it to him hot $\&$ he [James] is very sorry he made such a fuss about it now ... I can never feel the same towards him again, I think it was most ungentlemanly ... I will tell you all about it $\&$ all my little troubles some day. ${ }^{21}$

18 Jessie Campbell (at Maryborough) to Robert Philp (Brisbane), 17 February 1874, PFC.

19 Mary K. Brice, 'Jessie Bannister Philp: 1856-1890' in Allison Campbell and Morag B. Campbell, The James Campbell Story (Brisbane: Watson, Ferguson \& Co., 1990), 42-43.

20 The Brisbane to Sydney leg of the journey began on 19 February 1876 on board the City of Brisbane. A. Forsyth and the Campbells were among the passengers, and they were also on the list of passengers for the Sydney to England trip of the Osyth, departing on 26 February. See Week, 26 February 1876, 11; 'Departures', Sydney Morning Herald, 10 March 1876, 6. If the story is true, then Philp is likely to have said goodbye to Jessie on the Brisbane wharf. The fact that Philp is listed in the newspapers as departing Brisbane in March on the Egmont steamer suggests that the story may have veracity. See 'Departures', Week, 11 March 1876, 11.

21 Jessie to Bob, 8 June 1877, PFC. 
The other possible cabin romancer was 'Davy Reid' (who may have been the Captain David Reid that later worked for Burns, Philp \& Co. in the New Hebrides and Torres Strait islands). ${ }^{22}$

But absence appears to have made the heart grow fonder. On a short visit to Brisbane around May 1877, Robert asked for Jessie's hand in marriage, and she accepted. Philp wrote that he was 'sorry for Davy Reid but then you know Jessie my claim is a much better one than his. Certainly he is much handsomer $\&$ has a great many accomplishments I am without'. ${ }^{23}$ Jessie replied: 'So you think David Reid is much handsomer than you, he may be in the eyes of some but not in mine. ${ }^{24}$

Not long after the engagement, Philp returned to Townsville for the rest of the year, feeling that the business depended on his presence and commitment. Jessie was upset by their long separation:

I do not know what to do with myself after tea; I do not care to go out; \& it seems so long till bed-time. I miss you so much, \& sometimes when I think how short a time you were here \& all that happened I can hardly realise my happiness. Oh Bob, I thought you would never come back to me $\&$ many a sleepless night $\&$ miserable day have I had thinking over my unkindnesses to you ... some day when you know me better you will not think I was so cruel as I seemed to be. ${ }^{25}$

Adding to the couple's stress, a fire in October 1877 burnt down Philp's business premises in Townsville, ${ }^{26}$ underscoring Robert's reliance on his older partner, James Burns, to financially back him during commercial setbacks. Nevertheless, Jessie was able to console herself by forging links with her future father-in-law ('I saw your father last Sunday evening at church ... I think he is wearying to see his youngest boy. I know you are the spoilt bairn' $)^{27}$ as well as looking forward to a traditional 'white wedding':

I hope you will need to come down, but it will perhaps be better for you if you don't require to come. I would be very unwilling to part with you. It would be nice to see you so soon, but ... [January] will be here before you know where we are. If you do happen to pop in we won't shut the door. ${ }^{28}$

22 The Scottish-born Captain David Reid did not make his permanent home in Australia until 1887, but his obituary makes it clear that prior to this he made several voyages to Australia. Dying at the age of 76, he was roughly the same age as Jessie in 1876. 'Obituary: Captain D. Reid', Kyogle Examiner, 9 September 1932, 4. In her letters, Jessie guesses that Davy Reid learned of her engagement to Robert Philp from James Burns in Sydney, suggesting a business or shipping connection. See Jessie Campbell to Robert Philp, 14 June 1877, PFC.

23 Bob (Townsville) to Jessie, 27 May 1877, PFC.

24 Jessie to Bob, 8 June 1877, PFC.

25 Jessie to Bob, 11 May 1877, PFC.

26 'Destructive Fire in Flinders Street', Northern Miner, 3 October 1877, 3.

27 Jessie to Bob, 14 December 1877, PFC.

28 Jessie to Bob, 5 October 1877, PFC. 


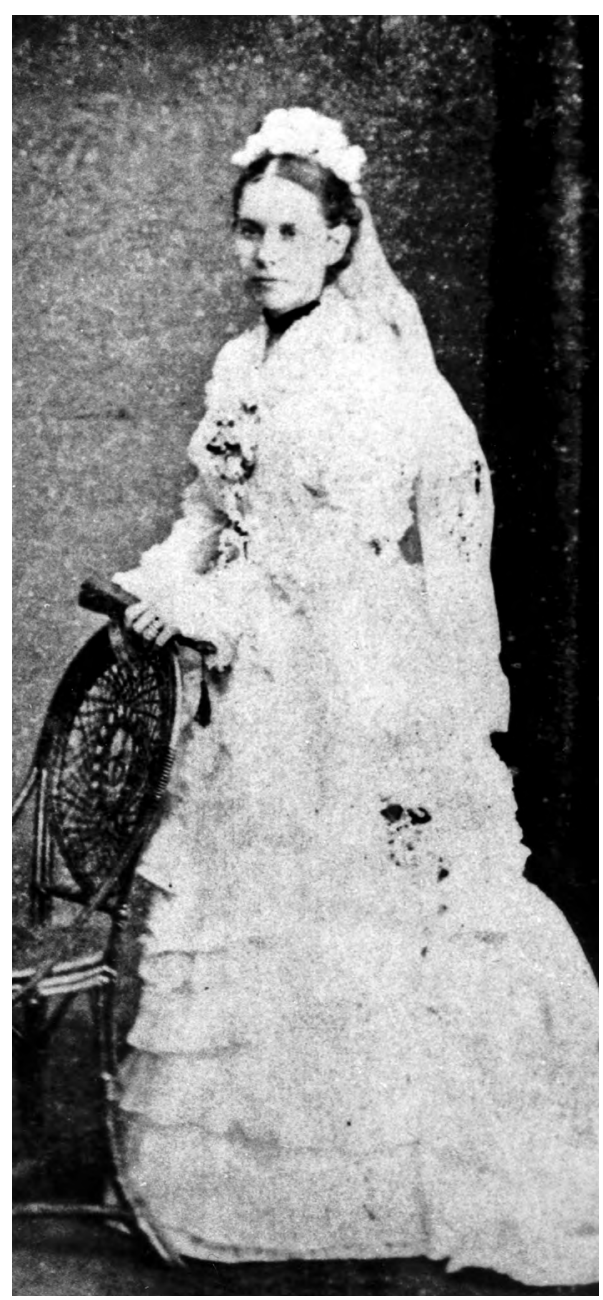

Figure 2: Jessie in her wedding dress, 1878.

Source: State Library of Queensland.
That Jessie's marriage to Robert was a love match tends to be confirmed in her correspondence. She shares her excitement with her sisters ('Nell \& Bella admire my ring very much $\&$ think you have displayed very good taste with it \& the locket'), ${ }^{29}$ and delights in sharing a somewhat 'saucy' Scottish dialect poem with her fiancé:

I dinna like love ava

That's written in a caird

I'd rather hast by word o'mow

In oor Rail yaird. ('At the back of the door would be better,' Jessie added.) ${ }^{30}$

A few days before becoming Mrs Robert Philp, Jessie's friend Madam Sloan wrote to her and reflected on what looked like the recipe for a happy marriage:

You will forgive me for writing to you won't you? But really I could not resist sending my congratulations, especially as I consider you have obtained (in the person of your future companion for life) what very few young ladies succeed in getting[:] that is a perfect gentleman in every respect ... I'm sure if he had reached all over the colony he could not have found such another darling as yourself ... just ask him. I know he will agree with me. ${ }^{31}$

29 Jessie to Bob, 25 May 1877, PFC.

30 Jessie to Bob, 31 May 1877, PFC.

31 M. Sloan (Jane Street, South Brisbane) to Jessie Campbell, 28 January 1878, PFC. 
Jessie married Robert on 1 February 1878 at the bride's parents' house, Ballymore, in the Brisbane suburb of Kelvin Grove. ${ }^{32}$ The couple settled in Townsville, building a home, 'Ellerslie', at the site where the Cathedral School (in the modern-day suburb of Mundingburra) has operated since $1958 .{ }^{33}$ In all, Jessie Philp gave birth to 9 children, including an unnamed stillborn child $(1880)^{34}$ and James Cleveland Philp, who died aged 5 months in $1884 .{ }^{35}$

Born on 28 December 1851, Robert Philp was over 4 years older than Jessie, typical of male-female age gaps in Australian colonial marriages at this time. ${ }^{36}$ That age gap probably felt wider at the time of their wedding, with Bob being 26 and Jessie not yet 22. Nevertheless, she was confident enough to share her opinions on Philp's business activities from time to time. ${ }^{37}$ For example, Jessie did not believe it made good business sense for Philp to involve his firm in the recruitment of indentured Pacific Islanders to work as canecutters in the sugar industry:

I think you have made a great mistake in going in to the labo[u]r trade. I think you will have plenty of trouble $\&$ expense with very little profit. ${ }^{38}$

Jessie's words were prophetic. The reputation of Burns, Philp \& Co. was damaged in 1884 by scandals involving two of their recruitment vessels. The Hopeful's captain and boatswain were convicted of murdering two recruits, and the Heath was seized by the Queensland Government and its 'cargo of Islanders repatriated after it was discovered that they were recruited in a deceptive manner'. Burns, Philp \& Co. soon abandoned the trade. ${ }^{39}$

Philp paid little heed to Jessie regarding his business, but he deferred to her over some household matters. The Philp home in Townsville was evidently a place where young bachelors enjoyed extended stays, probably while gaining experience working with Bob Philp. Some of these men were undoubtedly Jessie's brothers or cousins, and she did not want them to be exposed to bad influences:

32 'Marriage', Brisbane Telegraph (hereafter Telegraph), 5 February 1878, 2.

33 Ellerslie appears to have been officially part of the suburb of Aitkenvale during Philp's time, but the boundaries have subsequently changed over the years. For Ellerslie's history, see "Sap" Visits a Townsville Garden', Townsville Daily Bulletin, 4 October 1938, 5; Jess Cornelius, The Cathedral School of St Anne and St James, Townsville, 19172017, comp. Toni Lanphier (Preston, Vic.: Bounce Books, 2017), 51-56.

34 'Births, Marriages and Deaths', BC, 27 August 1880, 2. The stillborn child was the male twin of the surviving child, Colin.

35 'Births, Marriages and Deaths', $B C, 2$ August 1884, 1.

36 Beverly Kingston, The Oxford History of Australia: Volume 3: 1860-1900: Glad, Confident Morning (Melbourne: Oxford University Press, 1988), 118.

37 ' $[\mathrm{I}]$ see Joe has not done so well with his cattle after all, he will never make much at buying and selling I am afraid. Mrs Pen [Philp's housekeeper] would do better.' Jessie to Bob, 15 February 1883, PFC.

38 Jessie to Bob, 23 March 1883, PFC.

39 Lyndon Megarrity, 'Robert Philp: North Queensland Pioneer', Journal of the Royal Historical Society of Queensland 18, no. 4 (November 2002): 148-49. The Hopeful officers received life sentences but were pardoned in 1890. 
Harry [possibly Jessie's brother Henry Edwin Campbell] says in his letter to mother that Downey is not all nice, $\&$ that he marched about the house as if it was his own home. Neither he nor Robert can get on with him at all \& I think it is not very kind of you keeping him there \& making them uncomfortable. You will please me greatly by sending him off to fresh lodgings, besides Mrs Pen [Philp's housekeeper] has quite enough to do just now without him $\&$ if there is anything I dislike it is a cheeky boy about the house. The boys don't need any bad examples set them at home, they see enough at the store. You don't see these things I know, but Harry has complained two or three times now about him. ${ }^{40}$

Jessie had put her foot down, and Bob complied: 'Am glad you intend to send Downey away'. ${ }^{41}$ By pleasing Jessie, he was also pleasing Jessie's family, and that was important to her.

After Jessie and Robert's marriage, Jessie spent a number of extended holidays in Brisbane with the Campbell clan, taking her young children, including Isabella Mary ('May') (b. 1879), Colin (1880) and Charlie (1882) with her for company. By 1882-83, Jessie was travelling to Brisbane with a housemaid, Lucy Penwarn, who helped mind the children. Aged about 15 or 16, Lucy was not always popular with her mistress ('she is such a poor hand with the children ... I always get the heavy end of the nursing'), ${ }^{42}$ but her very presence reflected the Philp family's growing prosperity and the social expectations that came with Philp's role as an up-andcoming businessman:

May went to town [in Brisbane] with her Auntie Bella this afternoon, \& came home in a great state of excitement. 'Ah Mother I saw such a beautiful town $\&$ such beautiful dolls[,] one as big as this (stretching out her arms) if you buy it I shall take such care of it.' I said I have no money ... Willie Brown told her to take it \& say that her father's name was good. ${ }^{43}$

Jessie's southern journeys were partly designed to escape the Townsville summer and the uncomfortable wet weather that sometimes accompanied it. 'You can tell my friends I am not coming back 'til after the wet season,' Jessie told her husband, 'Two wet seasons are too much of a good thing altogether' ${ }^{44}$ But she also valued the

\footnotetext{
40 Jessie to Bob, 2 February 1883, PFC.

41 Jessie to Bob, 15 February 1883, PFC.

42 Jessie to Bob, 18 February 1883, PFC. A 'Lucy Pemwarn' is listed as travelling with Jessie and the children on their return trip to Townsville. See 'Shipping', BC, 24 April 1883, 1. Other relevant sources indicate that 'Pemwarn' was a misprint, and her real name was 'Lucy Florence Penwarn'. In 1914, 'Lucy' inserted a death notice for her father Joseph Penwarn in the Townsville Daily Bulletin (16 October 1914, 4), and 'L.F. Penwarn' thanked 'Hon. Robert Philp, Aitkenvale friends and others for their tokens of kindness and sympathy in her recent sad bereavement' (Townsville Daily Bulletin, 29 September 1914, 2). Her Queensland Death Certificate (1957/C/576) shows that Devonshire-born Lucy Florence Penwarn died on 19 December 1956 at the Eventide Home in Charters Towers, aged 89, signifying a birthdate of either 1867 or 1866. She had been in Queensland for 76 years, which fits in neatly with the period that Lucy was working for Jessie in the 1880 s.

43 Jessie to Bob, 29 December 1882, PFC.

44 Jessie to Bob, 15 February 1883, PFC.
} 
support of her parents during difficult times with the children. Regardless of social position, young mothers in Jessie's era were united by the potential terrors of infant sickness, for which the remedy was often trial and error:

Charlie has been very ill this week. He was very feverish \& out of sorts all day Monday ... I asked father what ... to do, to give another pack or a warm bath. Father advised the hot bath, \& mother took baby while Lucy \& I went to prepare it but before I was out at the door, Mother called out oh Jessie he is in convulsions, \& when I turned to look, I was terrified that we were going to lose him. Mother could scarcely hold him $\&$ his eyes were just starting out of his head. We had him into the bath in a few seconds, but he was not more than an hour out of it, when he took another fit $\&$ poor mother $\&$ I were just kept going the whole night with hot flannels \& water to prevent the fits coming on again ... I sent for the [Doctor] the first thing in the morning $\&$ when he came out he said we had done all we could $\&$ that there was nothing better than the hot fomentation $\&$ just to be very careful what we gave him to eat $\&$ not let him get any more cold (he had a dreadful cough $\&$ the Dr was afraid of congestion of the lungs) $\&$ if we saw any more signs of the fits returning to give him the same treatment ... Can't tell you how I felt all that night, but one thing I was thankful for, that I was beside Mother. I would have lost my presence of mind, if I had been alone. ${ }^{45}$

Perhaps due to the higher social standing of the Campbell family within Brisbane circles compared to the Philp clan, Jessie got away with some sharpness in her letter writing. For example, in responding to a letter in which Robert had gently suggested that she send at least some of their children back to Townsville, Jessie wrote: 'You say I must send May or Colin [Philp] back to keep the folks downstairs quiet. What is wrong with them $\&$ what makes you think there will be a big row some of these days?' 46

In what appears to be a subtle hint to his wife Jessie to return to Townsville from her Brisbane holiday in early 1883, Philp enclosed a poem by William Thomson in one of his letters: 'O! gin I had a [100] he'rts they'd beat for thee, they'd beat for thee'. ${ }^{47}$ The records are silent, but it can be speculated that the possible reason for Philp's subsequent departure from Townsville may have been at least partly due to his wife's preference to be close to her relatives. In 1886 Robert Philp was elected to Queensland Parliament and chose to reside in Brisbane with his family from then on.

There is little surviving correspondence by or to Jessie Philp after 1883, so there are gaps in her life story. Newspapers indicate that she went on a holiday in 1885 to New Zealand with her husband and the children, as well as her brother John Dunmore Campbell and his wife Mary (née Cameron). ${ }^{48}$ Jessie also spent some time in Sydney, possibly due to Robert Philp's need to consult James Burns over Burn,

45 Jessie to Bob, 25 January 1883, PFC.

46 Jessie to Bob, 18 February 1883, PFC.

47 See Bob to Jessie, 3 February 1883, PFC.

48 'Townsville', Week, 10 January 1885, 18; 'Along the Wharves', Evening News (Sydney), 15 January 1885, 4; Campbell and Campbell, The James Campbell Story, 21. 
Philp \& Co. matters. On 19 April 1887, while temporarily residing in Sydney, Jessie gave birth to her third daughter, Jessie Blanche, providing a new sister for May and Elsie (b. 1884). Another daughter, Doris, was born on 7 December 1888 in the Philp family home at 'Baroona' in the Brisbane suburb of Milton. ${ }^{49}$

As her private papers reveal, Jessie was a 'people person'. She kept a little black notebook in the 1880 s which included the 'Visiting Days' (e.g. ' 1 st and $3^{\text {rd }}$ Tuesdays') of a large range of acquaintances and friends. This list included the wives of a number of Queensland politicians, such as Lady McIlwraith, Mrs A. Norton and Mrs Macdonald Paterson. ${ }^{50}$ She was also not above gossiping about the ladies of Townsville:

I had a letter from Pollie Maffey yesterday asking me to get her a nice dress before I came back. I don't envy her her choice [of husband?]. I'm sure, unless he improves very much, she won't have a very happy time of $\mathrm{it}^{51}$... Surely that report is not true about Miss Love Bob? I would be sorry to see such a nice girl [throw] herself away on an old man ... 52

While her letters reveal a wide variety of personal passions, such as attending public lectures, ${ }^{53}$ watching regattas, ${ }^{54}$ dancing with her husband, ${ }^{55}$ listening to music and concerts, ${ }^{56}$ Jessie generally does not appear to have gone to many of the grand balls and society events that were covered in the Brisbane press. A notable exception was her attendance, with Robert, at the Brisbane Mayor's Ball in September 1889, commemorating 30 years of municipal government. ${ }^{57}$

49 Record of R. \& J. Philp children's names and birthdays, PFC; Elsie Maude Philp, Queensland Birth Certificate 1884/C/7952; Jessie Blanche Philp's birth notice, in $B C, 3$ May 1887, 4; Doris Margaret Philp's birth notice, in $B C$, 12 December $1888,4$.

50 Misc. item 23, in PFC. While there is no name on the book, internal evidence identifies it as belonging to Jessie. Among other clues, there is a list of recipients for 'Baby's photos' which include 'Mother ... Maggie [Margaret, the spouse of Philp's older brother, John Philp Jnr], Aggie [Robert Philp's sister Agnes], Bob [Jessie's name for her husband], Miss Pen [short for Lucy Penwarn?], Mrs Burns [presumably James Burns's spouse], Nell [sister Helen], Self, Bella [sister Isabella] ...' There are references in her letters to taking her children to be photographed at Matthewson's photographic studio in Brisbane: Jessie to Bob, 9 March 1883, PFC; Jessie to Bob, 30 March 1883, PFC; Jessie to Bob, 1 August 1879, PFC. In a list of expenses 'Pd Thursday 22 ${ }^{\text {nd }}$ Dec/87' a 'Lucy', probably Lucy Penwarn the maid, is listed as having been paid ' $2 / 6$ '.

51 Jessie to Bob, 2 February 1883, PFC.

52 Jessie to Bob, 15 February 1883, PFC.

53 'I have been to hear several of [Professor William] Denton's lectures, they are really splendid. He is talking of coming up our way [i.e. North Queensland] to look for [specimens,] shells \&c. but don't know whether he will lecture or not.' Jessie to Bob, 23 March 1883, PFC. Denton was giving a series of geological lectures within a Darwinian, evolutionary framework. See 'Professor Denton's Lectures', Bacchus Marsh Express (Vic.), 12 May 1883, 3.

54 'Father took Nell \& I for a drive this morning \& we waited to see one boat race on our way home. Brisbane was very gay $\&$ nearly ... every body had turned out to see the Regatta [a reference to the Anniversary Regatta, commemorating the official Separation of Queensland from NSW on 10 December 1859]'. Jessie to Bob, 10 December 1880, PFC.

55 'I see you \& Jim have been showing off your fine figures at the Ball. I might have honored you with a waltz if I had been there, but will reserve it for some future occasion.' Jessie to Bob, 4 July 1879, PFC.

56 'Father took Bella \& I to the Flower Show last night which was a great treat to me ... We had also the pleasure of hearing a fine brass band with several good singers, Miss Fanny Atkinson amongst the number.' Jessie to Bob, 19 January 1883, PFC. 'Father is going to take me to a concert on Monday night. This will be the first [she has attended while visiting Brisbane], so I have not been very dissipated have I?' Jessie to Bob, 4 July 1879, PFC. 57 'The Mayor's Ball', $B C, 6$ September 1889, 5. Another function Jessie attended: 'Lady Norman's Reception', $B C, 17$ May 1889, 6 . 
For the most part, however, Jessie increasingly seems to have become content being a relatively private person in comparison to her increasingly famous husband. Her final surviving letters were written to her eldest daughter May, who, along with her father and sister Elsie, was visiting Robert's older brother John Philp Jnr and his wife Margaret in Townsville (John worked as an accountant at the Hollis Hopkins store)..$^{58}$ 'Do not forget to take Elsie out to see your little brother's grave $\&$ try to get a few flowers before you go,' she reminds her daughter: Elsie was the twin sister of James Cleveland (Cleve) Philp, who died in Townsville as an infant in $1884 .{ }^{59}$ Jessie clearly found much personal meaning in maintaining strong ties with the extended family and raising thoughtful daughters:

I took the boys [Colin and Charlie] to the River on Saturday \& brought Aunt Elizabeth back with us for a few days. The boys did enjoy themselves \& eat oranges till they could hardly move. Tell Aunt Maggie [Margaret Philp], Aunt Elizabeth was asking for her \& wished to be kindly remembered to her. I suppose you have seen Mrs Pen ... How does Auntie feel with two big girls in the house? I hope you help her all you can ... I had to go to the dentist again today $\&$ he hurt me very much, but I think the worst is over now. I am afraid Father [Robert Philp] will be getting short of clothes, if he stays away much longer. Has he a respectable hat? ... Your loving mother Jessie B. Philp. ${ }^{60}$

Towards the final months of 1890, a heavily pregnant Jessie spent much of her energy nursing her infant daughter, Doris, who had caught scarlet fever, known for its painful red rashes and other symptoms such as nausea, sore throat and difficulty in swallowing. Shortly after the birth of her ninth child on 7 November, Jessie 'herself was seized with scarlet fever, and despite everything that could be done by the medical attendants' she died on 21 November at 'Baroona', Milton. Jessie Bannister Philp was 34 years old. According to the Brisbane Telegraph, 'Mr. Philp has been unremitting in his attention to his wife, waiting on her day and night and some anxiety is now expressed on his account' ${ }^{61}$ It was also especially traumatic for Jessie’s eldest daughter Isabella Mary (May):

On the back of May's Bible, beside the pressed petals of a red poppy, she has written in childish round hand: 'The last words my mother said were: "Oh, this terrible sickness!" The last words I heard her say were: "Have you got all you want. Good-bye."'62

58 'Mr. J. Philp', Week, 14 January 1910, 17; 'Mrs Margaret Philp', Daily Standard, 2 February 1935, 3. Margaret's maiden name was MacDiarmid.

59 Jessie to Isabella Mary Philp [aka 'May'], 26 May 1890, PFC.

60 Jessie to May, 2 June 1890 , PFC.

61 Telegraph, 21 November 1890, 5.

62 Brice, 'Jessie Bannister Philp 1856-1890', in Campbell and Campbell, The James Campbell Story, 44. 
The news of Jessie's death quickly reached her old friends in North Queensland. According to the Townsville Herald, Jessie:

was much beloved by the multitude of friends she had in Townsville. During a residence extending over many years the gentleness, kindly disposition, and gracious bearing of the deceased lady, her unostentatiousness and her benevolence excited universal admiration. The breaking up of 'Ellerslie', her home at Aitkenvale, and her departure with Mr Philp and her family to Brisbane ... was much regretted, and the time when she would again take up her residence in Townsville was always anticipated with the liveliest pleasure. The grief for a lady so much loved and respected is sincere and universal. ${ }^{63}$

After her untimely death, Jessie's husband and the children moved into his fatherin-law's residence in Kelvin Grove, where his sister-in-law Bella took care of the children. The youngest child, Helen Bannister Philp (known as Ivy), was adopted by Jessie's sister Nell and her husband, James Forsyth. ${ }^{64}$ Something of the impact that Jessie's death had upon Robert Philp can be seen in a letter he wrote to his eldest daughter soon afterwards: 'remember May your dear mother sees and knows all your thoughts and actions. Do nothing that will displease her'. ${ }^{65}$

Jessie Philp has generally not attracted much attention from biographers. Apart from some colourful correspondence, what we know of her is largely the cold, bare facts: Jessie Campbell married the fledgling Queensland businessman and politician Robert Philp, she enjoyed a privileged family life in Townsville and Brisbane, but died following childbirth at the early age of 34 .

Still, Jessie was significant to Queensland history for a couple of reasons. First, she was a representative of a group of elite Scottish families that were highly dominant in Queensland colonial politics and business for several decades. Female correspondence and participation in social events were part of the social glue that brought Scottish families such as the Campbells, the Petries, the Scotts, the Taits, the Philps, the Munros, the MacDiarmids and the Forsyths together in Queensland and kept family ties close as these Caledonian clans intermarried and interacted in business, social life and politics. ${ }^{66}$

63 'Death of Mrs Philp', Townsville Herald, 29 November 1890, 7.

64 Campbell and Campbell, The James Campbell Story, 21.

65 Robert Philp to Isabella May Philp, 6 January 1891, PFC.

66 It is beyond the scope of this article to account for the interconnectedness of Scottish business families in Queensland between 1860 and 1920, but the limited historiography suggests that having cultural ties in common was a source of emotional and financial support among migrant families in an unfamiliar colonial world. Stubborn cultural differences between European migrant groups, especially religious differences, influenced the Queensland Scots to retain close personal and business links with fellow Caledonians. See, for example, Patrick Buckridge, 'Robert Burns in Colonial Queensland: Sentiment, Scottishness and Universal Appeal', Queensland Review 16, no. 1 (2009): 69-78; Ruth Kerr, 'Love and Moffat's Store at Stanthorpe and the Beginnings of Moffat's Tin Mining Interests', Queensland History Journal 24, no. 6 (August 2020): 575-76; G.C. Bolton, 'Robert Philp: Capitalist as Politician' in The Premiers of Queensland, ed. Denis Murphy, Roger Joyce, Margaret Cribb and Rae Wear (Brisbane: University of Queensland Press, 2003), 6. For a broader discussion of Scottish-Australian networks in Australia in the nineteenth century, see Benjamin Wilkie, The Scots in Australia: 1788-1938 (Woodbridge, UK: The Boydell Press, 2018), chapter 2. 
Second, without his marriage to Jessie, it is likely that Robert Philp's political career would have taken a different path. Had Philp not married Jessie, it is doubtful that he would have resided in Townsville for over a decade. As Philp wrote to Jessie in 1877, 'my work don't seem so wearisome now that I have some one to work for/ before had often the feeling to clear out and go away sometimes to the diggings' ${ }^{67}$ Indeed, Philp's early years in Townsville were often unhappy. He was frequently in pain from fever (probably malaria), ${ }^{68}$ experienced a frosty reception from many local businessmen, ${ }^{69}$ and missed his family and friends in Brisbane. ${ }^{70}$

Undoubtedly, then, marriage and family responsibilities encouraged Philp to make his name as a merchant in North Queensland (1875-86). Representing northern electorates for nearly 3 decades (1886-1915), Philp's political identity and eventual rise to the Queensland premiership (1899-1903, 1907-08) was tied with North Queensland's development in a way it would not have been had he not married Jessie.

\section{From carpenter's daughter to Lady Philp: Mina's story}

Wilhelmina Fraser ('Mina') Munro, the second Mrs Philp, was born on 10 November 1867, a few heartbeats before her beloved twin sister Helena ('Miss Ellie'). She had 3 brothers: Edwin (b. 1865), James (1870) and Horatius Bonar, known as Horace (1878). At the time of her birth, Mina's 39-year-old Scottish-born father, John Munro, was a carpenter residing in Toowoomba. Also born in Scotland, her mother, Mary Anne, was the sister of James Campbell, the father of Jessie, the first Mrs Robert Philp. Hence Jessie and Mina were cousins, and part of the same extended family, business and social network that valued their Scottish heritage. ${ }^{71}$

67 Robert Philp to Jessie Campbell, 13 May 1877, PFC.

68 For reference to fever, see letters from Robert Philp to Jessie Campbell dated 13 May 1877, 10 June 1877 and 2 September 1877, PFC.

69 'The business people are a little jealous of me being comparatively a stranger and such a young single man they think I have no right to do so much business.' Robert Philp to Jessie Campbell, 20 May 1877, PFC.

70 Note, for example, Philp's reference to a Mr Whithall from Brisbane: 'his powers of conversation are not very good like myself but [I] always like to see anyone from Brisbane no matter who they are'. Robert Philp to Jessie Campbell, 9 September 1877, PFC. Elsewhere, Philp laments the lack of a rail link between Brisbane and Townsville: 'I would be content if I could only manage to be in Brisbane on Sunday evenings to take you home from Church'. Robert Philp to Jessie Campbell, 20 May 1877, PFC.

71 For information on this branch of the Munro family see Queensland Birth Certificates for Wilhelmina Fraser Munro (1867/C/2463), Helena (1867/C/2464) James John (1870/C/839), Horatius Bonar (1878/B/23035) and Edwin (1865/B/3737). See also 'Death of Lady Philp', Queensland Times (hereafter QT), 17 December 1940, 4; Campbell and Campbell, The James Campbell Story, 3. 
During the early 1870s, the Munro family moved to Brisbane, where Mina's father 'had a boot shop near Spring Hill'. ${ }^{72}$ In a letter to her fiancé Robert Philp, Jessie Campbell describes a visit to Ipswich involving 'Mina'. Most likely this is an early mention of Wilhelmina Fraser Munro. If this assumption is correct, Jessie was making a gently mocking reference to the then 9-year-old Wilhelmina as a future social butterfly:

There are two very nice gentlemen up here very sweet on Mina, but such a flirt I never saw/ she can keep them both going. She wants the one you promised, only she says he must be as good as you [Robert Philp] or he won't do. ${ }^{73}$

By 1884 Mina had developed a passion for music and dancing. She took lessons for several years with Mrs Newman, a popular Brisbane dance teacher, and performed waltzes and other steps of the day at a concert at the German Hall (South Brisbane) in 1888: 'Among the ladies whose dancing gave especial pleasure and reflected the greatest credit on their able instructress were ... the Misses Ellie and Mina Munro. ${ }^{.74}$

During her adolescence, Mina was also a notable pupil at Mrs O'Connor's school for girls at Edward Street, Brisbane. Run by the former headmistress of Brisbane Girls' Grammar, Mrs Jane O'Connor's school emphasised both scholarship and traditional female accomplishments, including music, drawing and craft. In 1884 Mina won school prizes for grammar, writing (probably handwriting), French, 'Conduct' and 'silence'. ${ }^{75}$ In that same year, she demonstrated her gifts as a scholar by winning the silver medal for geography when she sat for the University of Sydney Junior examination. ${ }^{76}$

Unlike her older cousin Jessie, Wilhelmina became a teenager at a time when educational opportunities for both girls and boys in Brisbane were noticeably expanding. Boosted by overseas migration, Queensland's non-Indigenous population increased from 30,059 (1861) to 213,525 (1881). ${ }^{77}$ This growth fostered a sense of permanent European settlement that encouraged Queensland parents to have greater expectations for their children's education, including, for a significant minority, that of their daughters. The establishment of the Brisbane Girls' Grammar School (1875) and the provision of female scholarships to grammar schools from 1876 were part of a movement by civic leaders such as former premier Charles Lilley

\footnotetext{
72 'Late Sir R. Philp', Western Champion, 17 November 1923, 16.

73 Jessie Campbell to Bob Philp, 31 May 1877, PFC.

74 'Mrs. Newman's Quadrille Assembly', Queensland Figaro, 21 April 1888, 3. See also 'Fancy Dress Ball', Queenslander, 22 November 1884, 827.

75 'Mrs. O'Connor's School', Telegraph, 22 December 1884, 5. See also Elisabeth Wheeler, 'Mrs Janet O'Connor: Educator and the Duporth School for Young Women: A Melba Connection', Queensland History Journal 23, no. 4 (February 2017): 255-69.

76 'University of Sydney: Junior Examinations', Queenslander, 13 December 1884, 964.

77 Ross Fitzgerald, Lyndon Megarrity and David Symons, Made in Queensland: A New History (Brisbane: University of Queensland Press, 2009), 24.
} 
to enhance the availability of secondary education for girls in the colony. Mina's higher-than-average education for the time probably reflected her position as a member of a moderately wealthy family, as well as the growing cultural assumption that female academic achievement need not challenge the gender norms of the age. ${ }^{78}$

Little is known of Mina's young adulthood, except that '[i]n her youth she was a member of the teaching staff of Duporth, Oxley, the school then conducted by the Misses O'Connor' ${ }^{79}$ Connected to the city via train, the school at Duporth (1888-1920) was the successor to Mrs O'Connor's school for girls in the city. Her daughters carried on the school after her death in 1895. As well as teaching at the school, Mina may also have taught privately. From 1893 to 1897, a 'Miss Munro' conducted 'Lessons in Music, French and Latin' at '18 Upper Edward Street'. ${ }^{80}$

During the mid-1890s, Robert Philp would have got to know Mina as a young teacher: it is likely that she taught some of his daughters, at least 4 of whom were enrolled in Duporth at various times between 1893 and 1908. ${ }^{81}$ Isabella Mary (May), the eldest, won a scholarship in December 1892 entitling her to enrol in Brisbane Girls' Grammar School, but either she or her father decided that Duporth was the best school for her. ${ }^{82}$ She won many school prizes, including one for 'ladylike conduct', and subsequently passed the Sydney University Junior examination twice. ${ }^{83}$

By contrast, Philp invested heavily in the education of his academically bright younger son, Robert Charles ('Charlie'), who studied at Brisbane Grammar School and King's School Parramatta, ultimately qualifying as a mining and metallurgical engineer at the Royal College of Science, South Kensington. ${ }^{84}$ While he cared for his daughters, it is likely that he at least initially saw the schooling of girls as a means of

\footnotetext{
78 Marion Mackenzie, 'Women in Queensland Education: The Experience of First Place-getters in the Scholarship 1873-1962', Journal of the Royal Historical Society of Queensland 20, no. 4 (November 2007): 139-40.

79 'Death of Lady Philp', QT, 17 December 1940, 4.

80 Telegraph, 11 July 1896, 1. See also BC, 20 February 1897, 1; Telegraph, 7 July 1894, 1; BC, 28 January1893, 2. The evidence is inconclusive. On the one hand, Miss Munro's advertisements last appear in 1897, the year before Mina's marriage and new role as a homemaker. On the other, Munro was a far from uncommon surname in southeast Queensland during the 1890s.

81 There are no references in newspaper reports on the Duporth School to Helen Bannister (Ivy) Philp, adopted by James Forsyth; she may have gone to Brisbane Girls' Grammar School. See 'Sydney University: Results of Junior Examination: Successful Queenslanders', $B C, 25$ July 1907, 4. For references to Philp's daughters at Duporth, see for example 'Duporth School', BC, 15 December 1893, 6; 'The Misses O'Connor School', BC, 13 December 1901, 6; 'Duporth School, Oxley', BC, 15 December 1905, 5; 'Duporth School', BC, 15 December 1908, 6.

82 'Grammar School Scholarships', BC, 24 January 1893, 7.

83 'Misses O'Connor's School', BC, 21 December 1895, 10. The Philp Family Collection (Fryer Library, University of Queensland) holds May's 1895 and 1896 Sydney University Junior Examination certificates.

84 Entry for R.C. Philp, in Queensland and Queenslanders (Brisbane: Australian History Publishing, Co., 1936), 230. The elder son's education is harder to trace. Colin Philp is likely to have gone to Brisbane Grammar, but there is no conclusive evidence. In 1898, he studied at Gatton Agricultural College and later pursued a career as a pastoralist. See F.E. Lord, 'Brisbane's Historic Homes: XXV. Mallow', Queenslander, 24 September 1931, 35; 'Gatton Agricultural College', BC, 31 August 1898, 5.
} 
providing marriageable, socially confident young women able to take their place in polite society. The annual prize-giving nights for Duporth college generally affirmed such notions:

The first part of the evening was devoted to a musical entertainment ... This was inaugurated by a grand march, which was executed with remarkable precision and effect. The deportment and the marching of the young ladies were especially striking. ${ }^{85}$

Philp as a politician did little to advance female suffrage, believing that economic development took precedence over electoral reform. ${ }^{86}$ Gradually, however, as the 1900s wore on, Robert Philp surprised himself by becoming an unequivocal supporter of a more public and political role for women in Queensland society. Addressing members of the Queensland Women's Electoral League in 1909, Philp argued that:

When the women of Australia learnt to use the power they possessed they could get any reasonable legislation they wanted. ... Mr. Philp dwelt upon the influence of women on the life of a nation ... He had been dubious at first as to the wisdom of allowing women to interfere in politics, but experience had convinced him that it was a good thing. They would never do anything to corrupt the politics of the State. ${ }^{87}$
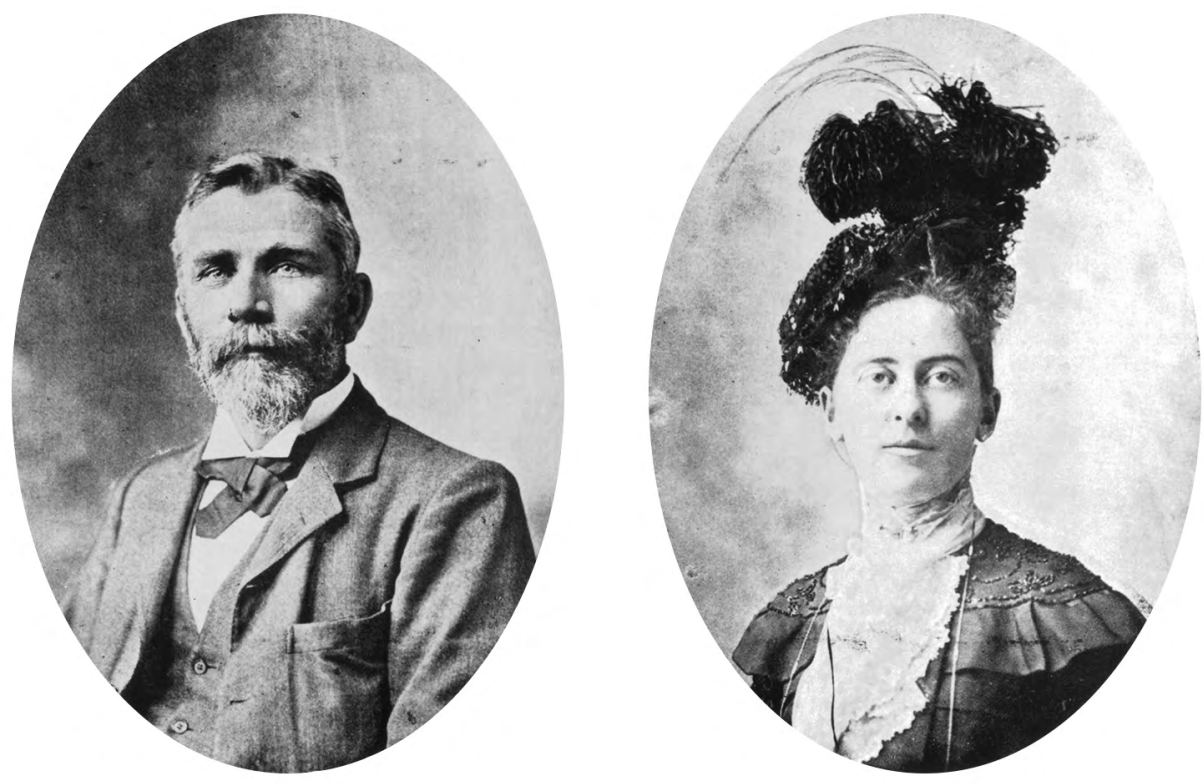

Figure 3: Robert and Mina Philp, circa 1900.

Source: State Library of Queensland.

85 'The Duporth School: Breaking Up', $B C$, 16 December 1904, 4.

86 See Megarrity, 'The Life and Times of Sir Robert Philp', 337.

87 Philp address, in 'Women as Antisocialists, Welcome to Delegates', Telegraph, 3 August 1909, 4. 
In a sense, the above quote showed the seasoned politician sniffing the winds of change: since 1903, Queensland women of European origin had been entitled to vote in Commonwealth elections and, similarly, 1905 legislation introduced female suffrage in Queensland's state elections. ${ }^{88}$ However, the second Mrs Philp probably influenced Philp's newfound appreciation of a wider role for women in public life beyond supporting their spouses. Aged 29 when she married Philp, Mina had lived a more independent life than Jessie and was able to use her position as the wife of a famous politician to develop a strong social standing and to further the causes she cared about.

Mina's marriage on 20 April 1898 to Robert Philp, Queensland Treasurer and Minister for Mines, naturally attracted much interest from the newspapers. Conducted by a Presbyterian minister, the wedding took place quietly at her parents' house in Brisbane. Owing to her father's illness, Mina was given away by her older brother, Edwin, and her sister, Miss Ellie, was her bridesmaid. The bride's 'lovely shower bouquet of bridal flowers was the gift of the bridegroom, as were the ruby and diamond brooch and bracelet'. The pair honeymooned in Toowoomba, Armidale and Sydney, before travelling up the coast in 'a Japanese boat to Thursday Island, stopping at all the places of interest on their way South [back to Brisbane]' ${ }^{9}$ After their honeymoon, Mina, Robert and the Philp children moved from Jessie's parents' house, Ballymore, to the 'Glen Olive' property in Toowong:

Mrs. Robert Philp was at home to a number of her young friends on Tuesday evening last. Dancing was entered into with much spirit, the large hall at Glen Olive giving ample room for the dancers. In fact, this charming riverside residence is particularly well adapted for entertainment purposes, and can accommodate a couple of hundred persons without undue crushing. ${ }^{90}$

Mina had thus started her married life as she intended to continue it. Her love of social activity and entertainment marked her time as the wife of a premier and well afterwards. She enjoyed a busy round of attending 'at home' days with the wives, daughters and other relatives of the (non-Labor) political, civil service and commercial elites, many of whom-such as the Forsyths, the Campbells and the Philps-were her cousins. Robert and Mina had no children of their own, but Mina appears to have forged reasonable relationships with the children from Robert's first marriage. Assisted by her stepdaughters, she organised numerous social events at 'Mallow', ${ }^{91}$ the Toowong residence the Philps called home from 1899:

88 Fitzgerald, Megarrity and Symons, Made in Queensland, 67.

89 “Wedding Bells: Philp-Munro', QT, 23 April 1898, 6.

90 'Social Doings: Telegraph, July 16', Week, 22 July 1898, 4. See also 'Women's World', BC, 25 May 1898, 7.

91 For details of the Philp's move to Mallow, see 'Women's World', BC, 29 June 1899, 7. 
Mrs. Robert Philp ... entertained over 100 guests at an enjoyable garden party at her residence ... The drawing room was beautiful, with red lilies, roses and wild flowers, and the dining-room and tea tables were ornamented with white flowers. Tea was also served in the garden ... Many beautiful gowns were worn. ${ }^{92}$

Mina employed her flair for social organisation (and the celebrity that came with being Robert Philp's wife) to lend support to various charities. Some of these charities were connected to her membership of the Presbyterian church. For example, in 1903 she opened a fundraising event for the Queensland Presbyterian Women's Missionary Union, where, amid the cakes and sweets, 'A number of Spears from the Mission Station, Mapoon, North Queensland' were made available 'for sale'. ${ }^{33}$ But Mina was also prominently involved with raising money for the Lady Lamington Hospital for Women from roughly 1900 to 1926, frequently serving as treasurer or co-vice-president of its committee (see Figure 4).$^{94}$ In 1900, she helped organise a 'Poster Fancy Dress Ball', where prominent Brisbane firms donated money for the privilege of being advertised on a prominent lady's frock or gentleman's costume:

Mrs. Robert Philp had an individuality all her own in a poster representing a large drapery firm [Chapman \& Co.]. ${ }^{95}$

As honorary treasurer for the poster ball committee, Mina subsequently handed Lady Lamington, the governor's wife, a cheque for $£ 465$, 'with the earnest hope that it may be the means of placing the Women's Hospital on a solid basis to be built upon year by year, and always remain a valuable memento of the time you spent with us'. ${ }^{96}$ Unlike Jessie, who was praised posthumously for being unostentatious, Mina's high public profile as the wife of a premier was affirmed by the press:

Mrs. Philp, by her charm of manner, the exercise of much tact, and her enthusiasm in social and charitable movements, has already achieved considerable [popularity] in a very wide circle. ${ }^{97}$

92 'Mrs. Robert Philp's Garden Party', BC, 29 October 1912, 9.

93 Advertisement, $B C, 6$ August 1903, 2. See also Advertisement for a Japanese fete opened (on the second day) by Mrs Robert Philp on behalf of the Enoggera Terrace Presbyterian Church Women's Guild, BC, 25 May 1901, 2.

94 The last reference to Mina's involvement on the committee in the newspapers is 1926, at least in the National Library of Australia's Trove collection of digitised newspaper sources. See 'Women's Realm', Daily Mail, 19 October 1926, 10.

95 'Poster Ball', Week, 28 September 1900, 6. 'N.B. - Business Firms and others are kindly requested to forward Donation Cheques to Mrs. ROBERT PHILP, Hon. Treasurer, Toowong.' Advertisement, Poster Ball, $B C$, 19 September 1900, 2.

96 'Cheque Paid Over', Telegraph, 10 October 1900, 2.

97 'Hon. Robert Philp, MLA and Mrs. Philp', Telegraph, 1 January 1901, 7. 


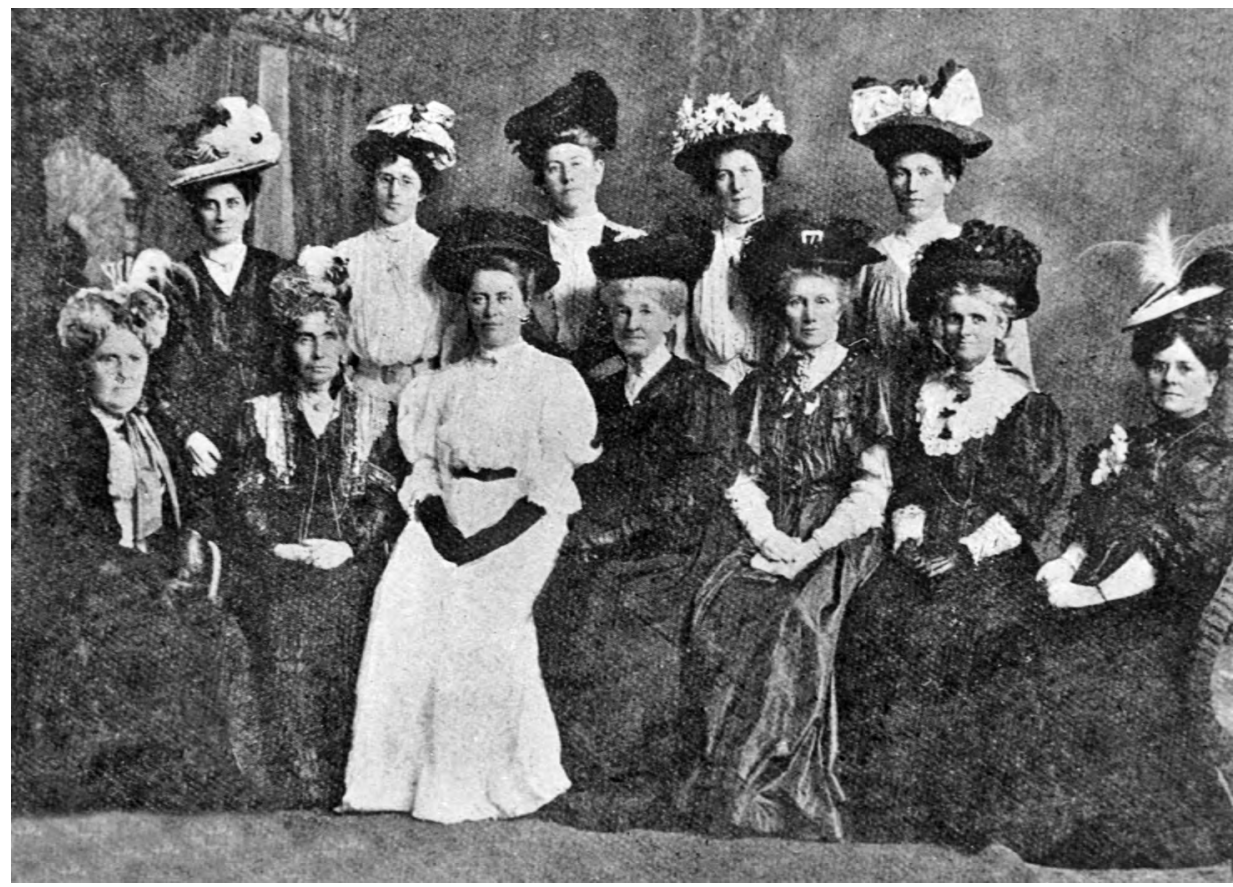

Figure 4: Members of the Lady Lamington Hospital Committee, 1908. Mina Philp is seated in the front row, wearing dark gloves and a white frock.

Source: State Library of Queensland.

Mina undoubtedly found pleasure in the social whirl of charity work, which gave her the opportunity to mingle with the powerful and, at least on one occasion, the legendary opera singer Nellie Melba, who in 1909 opened a 'Melba fete' in Brisbane to raise money for the Lady Lamington Hospital. ${ }^{98}$ Nevertheless, in her own way, Mina attempted to influence political debate and decision-making. As early as 1903, she was involved in a fruitless protest by several women against a decision by the Victorian Government to flog a prisoner (Mr Purdue) whose death sentence had been commuted to 15 years imprisonment:

Twenty-one 'women of Victoria and Queensland' recently presented a petition to the [Victorian] Premier, praying that the flogging portion of the sentence on Purdue might be remitted, on the ground that 'the use of the lash is brutalising,' and that 'the physique of a youth of seventeen is unable to bear the infliction of two floggings of 15 lashes without lasting injury ...' ... The petition seems to have come from Brisbane, the first signature being that of Mina F. Philp, wife of the Queensland State Premier and the final signature that of Amy Castles, the Victorian [opera singer]. ${ }^{99}$

98 'Woman's World: Melba Fete', BC, 29 June 1909, 7.

99 'Pity for Purdue', Herald (Melbourne), 29 August 1902, 8. 
In the 1910s, she campaigned for anti-Labor candidate and veteran Philp-supporter Edward H. Macartney when he successfully ran for the state seat of Toowong. ${ }^{100}$ Mina was far from radical in her views, but nonetheless it is clear that she was influenced by the moral arguments of sections of the female suffrage movement, which stressed that women had a civilising influence to play within public life. ${ }^{101}$ During World War I, she was a member of the Australasian League of Honour, 'aimed at binding together the women and girls of the Commonwealth and Dominion in the service of God and the Empire at this time of danger'. At a packed meeting of the Queensland branch:

Mrs. R. Philp moved that those present express their approval of the aims of the Australasian League of Honour, and pledge themselves to make a special effort during the time of war to uplift, strengthen, and purify national life. This was seconded by Mrs. Merrington, and carried enthusiastically. ${ }^{102}$

By now referred to as Lady Philp, following her husband's knighthood in 1915, Mina was heavily involved during World War I with the Toowong branch of the Red Cross, first as treasurer and later as president. She oversaw the raising of funds and clothing donations for the organisation, which, among other initiatives, set up a convalescent home for returned soldiers in Brisbane during February 1918:

The grounds are spacious ... It is proposed to commence a small poultry farm, which not only will provide the soldier inmates with ... eggs, but also will help to familiarise them with ... the many intricacies of egg production. ${ }^{103}$

Mina also raised funds for the Australian Soldiers Repatriation Fund, the highlight being her involvement with the Allies' Garden City held at the Brisbane Botanical Gardens (December 1916 to January 1917). Collecting a net profit of $£ 4,700$, the City boasted a Charlie Chaplin lookalike, a Japanese village, sideshow alley, concert bands, Santa Claus, confetti battles and places to get a meal: 'Lady Philp has taken over the management of the Café Chantant, and will be pleased to receive donations of cakes, scones ... also volunteers to assist. ${ }^{104}$

The early 1920s must have been a difficult time of adjustment for Mina. Sir Robert Philp died in 1922, and she moved to the outlying suburb of Clayfield. Philp's eldest daughter May subsequently took over 'Mallow' as her own private residence.

100 'Lady Philp', Queensland Figaro, 16 January 1915, 7.

101 Mark Peel and Christina Twomey, A History of Australia (Basingstoke, UK: Palgrave Macmillan, 2011), 120.

102 'Australasian League of Honour', $B C, 4$ August 1915, 11.

103 'Convalescent Home', Telegraph, 15 February 1918, 9. For Mina’s role in the Toowong branch, see Telegraph, 28 July 1915, 8; 'Red Cross', BC, 21 March 1917, 8.

104 'Allies Garden City', Telegraph, 21 December 1916, 11. See also 'The Allies' Garden City', QT, 17 January $1917,7$. 
'Mallow' may have held too many memories for Lady Philp, or it just might be that given that most of the furniture was from the 1880s (and chosen by the first Mrs Philp), the Toowong residence may never have really felt like 'home'. ${ }^{105}$

During the interwar period, Lady Philp explored her love of literature by joining the Queensland branch of the Dickens Fellowship, as well as the Brisbane Lyceum Club, a meeting place for women interested in a range of topics such as arts, literary matters and current affairs. ${ }^{106}$ As Sir Robert Philp's will had left her comparatively wealthy, she was also able to indulge her love of overseas travel. ${ }^{107}$ As early as 1910 , Mina had travelled with her sister to 'Banda, Java, Malay States, Japan and the Philippines', ${ }^{108}$ and in the 1920s and 1930s, she took a number of extended tours, chiefly to the United Kingdom but also visiting the United States and Canada. ${ }^{109}$

Sadly, her North American trip of 1929-30 was cut short by the death of her sister and travelling companion, Miss Ellie Munro. On her return to Brisbane, she was interviewed about her US experiences. While she was impressed by the supposed success of prohibition ('I did not see ten intoxicated men') ${ }^{110}$ and the presidency of Herbert Hoover, there was much she found lacking. The American diet seemed odd ('Coffee largely takes the place of tea ... At first ... I thought the whole population lived on lettuce'); ${ }^{11}$ the US school system suffered from a crowded curriculum 'so that $\ldots$ specialisation was affected'; ${ }^{112}$ and while she admired the 'beautiful tenor voice' of the African-American singer Roland Hayes, the version of Handel's Messiah she heard in America did not compare with those she'd enjoyed in Brisbane ('they are not a singing nation like we are'). ${ }^{113}$

Lady Mina Philp died on 15 December 1940 , leaving an estate worth $£ 26,098$ to be 'shared among her relatives'. ${ }^{114}$ Frailness had slowed down her social life, but towards the end she was still taking an interest in current affairs, donating to the 'British Bombing Victims' Fund' and the Red Cross Society as World War II was in its early stages. ${ }^{115}$

105 F.E. Lord, 'Brisbane's Historic Homes: XXV. Mallow', Queenslander, 24 September 1931, 35.

106 'Death of Lady Philp', QT, 17 December 1940, 4. For the Lyceum Club, see Ruth Kerr, Enquiring Minds:

Women of the Lyceum Club Brisbane, 1919-2019 (Brisbane: Lyceum Club of Brisbane, 2019), 40.

107 Bolton, 'Robert Philp: Capitalist as Politician', 25.

108 'Social and Personal', Telegraph, 16 November 1910, 7.

109 'Lady Philp: Education Methods Abroad', Telegraph, 6 December 1930, 2; 'Lady Philp Returns from England',

Telegraph, 30 January 1939, 11; 'Scotland's Beauty', Telegraph, 26 January 1935, 39.

110 'Lady Philp: Impressions of America', Week, 12 December 1930, 9.

111 'Lady Philp: Impressions of America', Week, 12 December 1930, 9.

112 'Lady Philp: Education Methods Abroad', Telegraph, 6 December 1930, 2.

113 'Lady Philp: Impressions of America', Week, 12 December 1930, 9.

114 'Lady Philp's Estate', Evening News (Rockhampton), 24 April 1941, 7.

115 'How the British Bombing Victims' Fund is Growing', Telegraph, 18 September 1940, 5; 'Red Cross Special Appeal', Telegraph, 13 November 1940, 16. 


\section{Conclusion}

When Robert Philp gave up his position as parliamentary leader of Queensland's conservative party in 1908, a function was held in which his colleague declared:

We are not unmindful of the sacrifices Mrs. Philp has made, and we therefore ask Mr. Philp to accept, for her, a handsomely fitted dressing case. ${ }^{116}$

The first Mrs Philp received no such public acknowledgment of her role. Born and raised at a time when educational opportunities for young girls were limited, and married at a time when masculine culture dominated public events in Townsville and Brisbane, Jessie has largely been lost to history except for her very private letters. Mina, by contrast, was fortunate to have been born just a decade after Jessie. As a young woman, she benefited from a broader education, her husband's high profile and a growing belief, partly influenced by female suffrage, that women were entitled to a larger role in the public life of the nation than they had previously been permitted.

What a difference a decade made!

116 Harry C. Perry, Memoirs of the Hon. Sir Robert Philp K.C.M.G. 1851-1922 (Brisbane: Watson, Ferguson \& Co. Ltd, 1923), 264. 
This text is taken from Australian Journal of Biography and History: No. 4, 2020, published 2020 by ANU Press, The Australian National University, Canberra, Australia.

doi.org/10.22459/AJBH.04.2020.02 